\title{
Cell Mediated Immunity Dysfunction Retrieval Using the Extracts of the Plant Cassytha capillaries (Meissen)
}

\author{
A.J.A. Ranjitsingh ${ }^{1 *}$, C. Padmalatha ${ }^{1}$, G. Athinarayanan ${ }^{2}$ and P. Dhasarathan ${ }^{3}$ \\ ${ }^{1}$ UGC Emeritus Fellow \\ ${ }^{2}$ Department of Microbiology, Sri Ram Nallamani Yadava College of Arts and Science, \\ Tenkasi, India \\ ${ }^{3}$ Department of Biotechnology, Prathyusha Engineering College, Chennai, India \\ *Corresponding author
}

\section{A B S T R A C T}

\begin{tabular}{|l|}
\hline K e y w o r d s \\
Immunity, \\
$\begin{array}{l}\text { Immunity booster, } \\
\text { Natural products, } \\
\text { DTH, Cassaytha } \\
\text { capillaries }\end{array}$ \\
\hline Article Info \\
\hline $\begin{array}{l}\text { Accepted: } \\
\text { 26 June } 2018 \\
\text { Available Online: } \\
\text { 10 July } 2018\end{array}$ \\
\hline
\end{tabular}

\section{Introduction}

Cell mediated and antibody mediated defensive mechanism in the immune system protects the body against the invasion of infectious and opportunistic microorganisms and spontaneously arising Neoplasm (Dean et al., 1994). Bannerjee et al., (1996)and Ranjitsingh and Sujatha (2012) and Ranjitsingh and Dhasarathan (2011).

As pesticides are extensively used in farming and insect control, it has every chance to get in to the human body through food, water, air
The growing incidence of infectious diseases, autoimmune problems and tumour formation are due to the weakness/dysfunction of immune system. Many xenobiotic components that enter human system through food, air and food chain interferes with the functioning of cells and secretions that offer immunity. Pesticides that are being indiscriminately applied get into the human system had been reported to affect the functioning of immune system. To validate this information, in the present study a commonly used organophosphorus pesticide Quinolphos was administered to Swiss albino mice and the functioning of cell mediated immunity was measured using Delayed Type Hyper Sensitivity Reaction (DTH) using sheep red blood cells as a challenging antigen. The pesticide induced a reduction in TH response. So to improve the DTH dysfunction remedial measures were tried using Standard immune boosting drugs and the extract of a plant Cassytha capillaries. The remediating agents were found to retrieve the lost immunity to a significant level. 
the extract of the plant Cassaytha capillaries. The outcome of the study will help to develop immunity enhancing natural products.

\section{Materials and Methods}

Extraction of phytochemicals from the plant $C$. capillaries

For the present study a parasitic twinner plant Cassytha capillaries (Meissen) was collected from trees in Western Ghats region of Tamil Nadu. The whole plants were shade dried and powdered when dried. The dried powder was used to take extract using the solvent methanol in Soxhelet apparatus. The extract was dried, purified and stored.

\section{Selection of experiment animal}

For the experiments, Swiss albino mice (age 45 - 60 days) were selected. The mice were fed regularly with water and pellet feed.

\section{Selection of pesticide}

For the present study an organophosphorous pesticide, Quinolphos was chosen. Using Standard methods, LC 50 value was fixed. From this LC 50 value, a sub lethal dose of 0.1 ppm was chosen for the immune suppression studies.

The sub lethal dose was dissolved in water and given to the animal through oral route. Weighed quantity of the extract was dissolved in sterilized distilled water, and three concentrations were prepared, viz., 50, 100 and $200 \mathrm{mg} / \mathrm{kg} / \mathrm{day}$. The plant extract dissolved in water was fed to the mice along with drinking water using a special feeding bottle Quinolphos (Organophosphorous pesticide $0.1 \mathrm{ppm}$ ) was used as a immune suppressant drug. Proimmu (Envin Bioceuticals, Shorapur, India was used as standard immune potentiating drug).

\section{Antigen (SRBC) preparation}

To prepare cellular antigens, sheep erythrocytes were obtained from fresh blood of sheep sacrificed in a local slaughter house. Sheep blood was collected into Alsevier's solution and stored. Sheep red blood cells (SRBC) were prepared by washing sheep blood in Alsevier's solution thrice by centrifuging at $3000 \mathrm{rpm}$ for 10 minutes. Packed volume of SRBC is resuspended to get a concentration of $0.1 \mathrm{ml}$ containing $1 \times 10^{8}$ cells for immunization and challenge.

\section{Delayed Hyper Sensitivity response (DTH) Assay}

\section{SRBC challenge}

DTH assay was carried out using Sheep Red Blood Cells (SRBC) as challenging antigen.DTH response in control, standard immune booster drug administered, immunity, suppressed and natural product given mice was determined using the method described by Agarwal et al., (1999).

Mice were divided in to eight groups each group containing six mice. Drugs were given to various groups i.e.

$\begin{array}{llll}\text { Group I } & - & \text { Control } & \\ \text { Group II } & - & \text { Plant extract given }\end{array}$ (dose levels of $50 \mathrm{mg} / \mathrm{kg}, 100 \mathrm{mg} / \mathrm{kg}$ and $200 \mathrm{mg} / \mathrm{kg}$ ).

Group V - $\quad$ Standard immune potentiating drug given Proimmu (30 mg/kg).

Group VI - Quinolphos

(Organophosphorous pesticide) $\mathrm{Cl}_{2} \mathrm{H}_{15} \mathrm{~N}_{2} \mathrm{O}_{3}$ immune suppressant

Group VII - C. capillaries extract (200 mg/kg), and Quinolphos (0.1ppm) treated group.

Group VIII - Proimmu (30 mg) and Quinolphos (0.1 ppm) treated group 
Mice were sensitized by injecting $0.1 \mathrm{ml}$ of SRBCs suspension containing $1 \times 10^{8}$ cells in the nape of the neck on day 0. Plant extracts were given to the mice from three days prior to the sensitization and continued till day 7 . On day, 7, mice were challenged by sub cutaneous injection of $0.02 \mathrm{ml}$ of SRBCs $(1 \mathrm{x}$ $10^{8}$ cells $/ \mathrm{ml}$ ) in right hind foot pad. The left hind foot pad was given normal saline $(0.02 \mathrm{ml})$. Paw thickness was measured after 24, 48, 72 and $96 \mathrm{hrs}$ using Vernier calipers (Mitotoya digital meter). The difference between the left and right foot thickness, expressed in $\mathrm{mm}$ was taken as a measure of DTH.

Quinolphos and Proimmu were administered to groups V and VI along with feed for 3 days prior to sensitization with SRBC. For group VII, the extract of $C$. capillaries $(200 \mathrm{mg} / \mathrm{kg})$ was given along with Quinolphos (0.1 ppm) for 3 days prior to sensitization with SRBC.

For group VIII Standard immunopotentiating drug proimmu and Quinolphos (0.1 ppm) were given 3 days prior to sensitization with RBC.

Plant extracts and proimmu were given through drinking water from day-3 until $7^{\text {th }}$ day. Skin reactions at the site of SRBC injection were carefully monitored for $72 \mathrm{hrs}$. A positive reaction to SRBC was indicated by edema and induration at the site, measuring 2$5 \mathrm{~mm}$ diameter. Positive responses were graded as follows,

1. Erythema (+)

2. Erythema with induration $(++)$

3 . Erythema with induration and small blisters $(+++)$

4. Erythema with induration and large blisters $(++++)$,

The responses $2+, 3+$ and $4+$ were accepted as evidence for positive reactivity.

\section{Results and Discussion}

\section{Delayed type hypersensitivity reaction assay}

Delayed Type Hypersensitivity (DTH), an expression of cell mediated immune response has been used to asses' immunomodulatory mechanism in animals. The DTH assay is a simple and inexpensive method to assess immune response (Doherty, 1981). Immunosuppressive chemicals elevate DTH response by eliminating the population of $\mathrm{T}$ suppressor cells (Turke et al., 1976 and Gill and Liew, 1978). The DTH response to antigenic challenge (SRBC - Sheep Red Blood Cell) provides a useful system for identification of compounds with selective effect on the immune response (Khurana et $a l ., 2013)$. The most commonly used in vivo assay to determine DTH response is antiinflammatory cutaneous reaction. Okoli et al., (2003) have identified some active principles like lupeol, premnazole, usnic acid, pinitol zanhasaponins A and B etc. in several plants to function as anti-inflammatory agents. In the present study the T-cell response (CMI) level in the form of DTH response in an experimental mice was assessed after administering the C.capillaries extracts and immunosuppressive pesticides (Table 1 and 2).

DTH reactions in mice after SRBCs antigenic challenge was tested for normal, immunity suppressed (Quinolphos given) and immunity stimulated mice (C.capillaries extracts and Proimmu). DTH response was high in Proimmu (Standard drug) treated groups the antigenic challenge by SRBC resulted in a significant increase in foot pad thickness in left paw (receiving SRBC), than right paw (receiving normal saline as control) (Table 1 and 2). The percentage decrease in paw edema in Quinolphos treated cases was $58.33 \%$ but in C.capillaries treated group $(200 \mathrm{mg} / \mathrm{kg})$, it got 
increased to $28.2 \%$. In Proimmu treated mice also there was a significant increase in DTH response. In the mice treated with C.capillaries and Quinolphos, the DTH was significantly improved $(+10.26 \mathrm{P}<0.05)$. The comparison of these results indicates that the extracts of C.capillaries have immunopotentiating effect like the standard immunostimulant drug Proimmu.

According to Tiwari et al., (2004) the active principle, sesquitepene lactone present in the plant Tridax procumbens assisted in cell mediated immune response and enhanced DTH reaction, which was reflected from the increased foot pad thickness due to heightened infiltration of macrophages to the inflammatory site, Datta et al., (1999) reported that the active fraction CI-1-Protein in the plant pigeon pea Cajanus cajan enhanced DTH response significantly in mice on SRBC antigenic challenge. Histological investigation by (Datta et al., 1999) on the inflammatory site showed perivascular cuffing with mononuclear cells followed by a more extensive exudation of mono and poly morphonuclear cells. The effector cells that promote DTH reactions ( $\mathrm{T}_{\mathrm{DTH}}$ cells) cause the activation of macrophages, infiltration of polymorphonuclear cells, increased vascular permeability and odema, thereby it induced Tcell mediated response (Gokule et al., 2003) also observed an elevation in DTH response in mice treated with the plant extract, Argyreia speices and challenged with SRBC and this was due to the effect of plant drug on $\mathrm{T}$ - lymphocyte and accessory cell types required for the expression of reaction (Luster et al., 1982). According to (Hirschman et al., 2001) the extracts of the plant Cyttaria spp was able to elevate the DTH response due the activation of CD4 (+) and CD $8(+)$ T cells as reported earlier (Gorbachev et al., 2001).

Animals treated with Quinolphos had a suppressed foot pad thickness indicating the suppressive act on cell mediated immunity. According to (Osario and Goldman., 2017), the DTH response is associated with T-cells and sensitized T-cells release mediators to promote inflammatory processes. The possible mechanism behind DTH reactions, include, activation of complements, releasing of mediators by activated mast cells; kinin reactive oxygen or nitrogen species by archidonic acid metabolites histamine and proinflammatroy cytokines (Argus and Woo., 1995). Tiwari et al., (2004) stated that the delayed type hypersensitivity reaction is characterized by large influxes of non-specific inflammatory cells, in which macrophage is a major participant. DTH reactions develop when antigen activities sensitized $\mathrm{T}$ ртн cells. These cells generally appear to be a $\mathrm{T}$ DTH cells subpopulation although sometimes $\mathrm{T}$ cytotoxic cells are also involved. Activation of $\mathrm{T}$ delayed type hypersensitive $\left(\mathrm{T}_{\mathrm{DTH}}\right)$ cells by antigen presented through appropriate antigen presenting cells results in the secretion of various cytokines including interleukin-2, interferon- $\Upsilon$, macrophage migration inhibition factor and tumor necrosis factor $\beta$.

Table.1 Effect of Extracts of C.capillaries and standard immunomodulating drug on SRBC induced DTH responses in Swiss albino mice

\begin{tabular}{|l|l|c|}
\hline \multicolumn{1}{|c|}{ S.No } & \multicolumn{1}{|c|}{ Experimental Group } & DTH Response to SRBC \\
\hline $\mathbf{1}$ & Control & $++(0)$ \\
\hline $\mathbf{2}$ & Immunosuppressed & $++++\left(4^{+}\right)$ \\
\hline $\mathbf{3}$ & C.capillaries $(50 \mathrm{mg} / \mathrm{kg})$ & $+++\left(3^{+}\right)$ \\
\hline $\mathbf{4}$ & C.capillaries $(100 \mathrm{mg} / \mathrm{kg})$ & $++\left(2^{+}\right)$ \\
\hline $\mathbf{5}$ & C.capillaries $(200 \mathrm{mg} / \mathrm{kg})$ & $+(1)$ \\
\hline
\end{tabular}


Table.2 Effect of the extracts of C.capillaries on delayed hypersensitivity (DTH) reactions. (Foot pad thickness - NS- non significant, $a=p<0.01, b=p<0.001$ )

\begin{tabular}{|c|c|c|c|c|c|c|}
\hline \multirow[t]{2}{*}{ Group } & \multirow[t]{2}{*}{ Substance } & \multirow[t]{2}{*}{$\begin{array}{c}\text { Dose } \\
\mathrm{mg} / \mathrm{kg}\end{array}$} & \multicolumn{3}{|c|}{$\begin{array}{l}\text { Mean diameter of foot pad thickness } \\
\qquad(\mathrm{mm}) \pm \mathrm{SD}\end{array}$} & \multirow{2}{*}{$\begin{array}{c}\text { Test of } \\
\text { singnificance } \\
(24 \mathrm{hrs})\end{array}$} \\
\hline & & & $24 \mathrm{hr}$ & $48 \mathrm{hr}$ & $72 \mathrm{hr}$ & \\
\hline I & $\begin{array}{c}\text { Control sterile } \\
\text { water }\end{array}$ & & $0.39 \pm 0.02$ & $0.30 \pm 0.06$ & $0.21 \pm 0.02$ & Group I Vs II ${ }^{\mathrm{a}}$ \\
\hline II & $\begin{array}{l}\text { C.capillaries } \\
\text { extract }\end{array}$ & 50 & $\begin{array}{c}0.42 \pm 0.04 \\
(+7.69)\end{array}$ & $0.31 \pm 0.04$ & $0.15 \pm 0.02$ & Group I Vs III $^{\mathrm{a}}$ \\
\hline III & $\begin{array}{l}\text { C.capillaries } \\
\text { extract }\end{array}$ & 100 & $\begin{array}{c}0.46 \pm 0.03 \\
(+17.95)\end{array}$ & $0.26 \pm 0.04$ & $0.18 \pm 0.02$ & Group I Vs IV \\
\hline IV & $\begin{array}{l}\text { C.capillaries } \\
\text { extract }\end{array}$ & 200 & $\begin{array}{c}0.50 \pm 0.07 \\
(+28.21)\end{array}$ & $0.30 \pm 0.07$ & $0.2 \pm 0.02$ & Group I Vs V \\
\hline $\mathbf{V}$ & Quinolphos & 30 & $\begin{array}{c}0.18 \pm 0.4 \\
(-58.33)\end{array}$ & $0.23 \pm 0.02$ & $0.8 \pm 0.10$ & Group I Vs V \\
\hline VI & Proimmu & 30 & $\begin{array}{c}0.58 \pm 0.06 \\
(+48.32)\end{array}$ & $0.34 \pm 0.14$ & $0.20 \pm 0.12$ & Group I Vs VI ${ }^{b}$ \\
\hline VII & $\begin{array}{c}\text { C.capillaries } \\
\text { extract } 200 \mathrm{mg} / \mathrm{kg} \\
\text { with Quinolphos } \\
30 \mathrm{mg} / \mathrm{kg}\end{array}$ & 230 & $\begin{array}{l}0.38 \pm 0.07 \\
(-2.56)\end{array}$ & $0.26 \pm 0.13$ & $0.19 \pm 0.02$ & Group I Vs VII $^{\text {NS }}$ \\
\hline VIII & $\begin{array}{l}\text { Quinolphos with } \\
\text { Proimmu (each } \\
\text { 30mg/kg) }\end{array}$ & 60 & $\begin{array}{c}0.43 \pm 0.04 \\
(+10.26)\end{array}$ & $0.36 \pm 0.10$ & $0.24 \pm 0.06$ & Group I Vs VIII ${ }^{\mathrm{a}}$ \\
\hline
\end{tabular}

The overall effects of these cytokines are to recruit macrophages into the area and activate them, promoting increased phagocytic activity vis-à-vis increased concentration of lytic enzymes for more effective killing. (Argus and Woo., 1995) reported that the immunosuppressive Quinolphos have profound suppressive effect on all forms of DTH and cell mediated immunity. Animals treated with Quinolphos and receiving C.capillaries extract showed a significant counteracting effect to Quinolphos induced Tcells suppression.

According to Gilberston et al., (2002) the body's immunity has been suppressed in diseases like cancer and AIDS. The chemotherapy and radiation therapy in cancer treatment contribute to depress the immune system. As side effects are associated with these synthetic modulations, plant drugs like C.capillaries can be co administered along with chemo therapeutic agents.

In the present study the report on the extracts of C.capillaries indicate that the active compound of this plant can be used for chemo protection against the toxicity induced by pesticide and the combination of the active compounds with receptors of immune system can elevate immune response.

\section{Acknowledgement}

Dr.A.J.A.Ranjitsingh is thankful to UGC for providing Emeritus fellowship to continue this work. 


\section{References}

Arguss M.F., Woo Y.T., 1995. Chemical Induction and cancer. http//book.google.co.in/sbn146124076 $\mathrm{X}$

Bach, J.F., 1976. The pharmacological and immunological basis for the use of immunosuppressive drugs. Drugs 11, 1-3

Banerjee, B.D., Ray, A., Sen, P., 1996. Modulation of humoral and cell mediated immune responses by Azadirachta indica in mice. Indian Journal of Ethnopharmacology. 72, 283-286.

Datta, S., Basu, K., Sinha, S., Bhattacharyya, P., 1998. Hepatoprotective effect of a protein isolated from Cajanus indicus (Spreng) on carbon tetrachloride induced hepatotoxicity in mice. Indian Journal of Experimental Biology. 36, 175-181.

Dean M, Allikmets R, Gerrard B, Stewart C, Kistler A, Shafer B, Michaelis S, Strathern J., 1994. Mapping and sequencing of two yeast genes belonging to the ATP-binding cassette superfamily. Yeast 10(3):377-83

Dhasarathan P, A.J.A.Ranjit Singh and Paulisis, (2011). Evaluation of cellular immune response in mice exposed to pesticides. Asian Journal of Phar.Biol. Research. 1(1): 47-53.

Doherty, N.S., 1981. Selective effect of immunosuppressive agents against the delayed hypersensitivity response and humoral response to sheep red blood cells in mice. Agents Actions 11, 237 242.

Gilberston M.K., et al., 2003. Immuno suppression in the Northern Leopard Frog (Rana pipens) induced by pesticide exposure. Environmental Toxicology. Chem. 22 (1): $101-10$.

Gill, H.H., Liew, F.Y., 1978. Regulation of delayed hypersensitivity III. Effect of cyclophosphamide on the suppressor cells for delayed hypersensitivity to sheep erythrocytes in mice. European Journal Immunology. 8, 172-176.

Gorbachev, AN., Heeger, P.S., Fairchild, R.L., 2001. CD4 and CD8 T cell priming for contact hypersensitivity occurs independently of CD40-CD 154 interactions. Journal of Immunology 166(4), 2323 - 2332.

I. Joseph, A.J.A. Ranjit Singh, C. Padmalatha and J. Savarimuthu Michael, (2012) Prevalence of extended spectrum $\beta$ lactamase mediated resistance in gram negative urinary tract isolates. Journal of Parama 1(1): 40-46.

Khurans.K, Chauhan S.K., 2012. Immunotoxic effect of cybermethinin on Delayed hypersenstitivity (DTH) reaction. The Indian veterinary Journal. 76 (12): 1055 - 1057.

Luster, M.L., Dean, J.H., Boorman, G.A., 1982. Cell mediated immunity and its application in toxicology. Environmental Health perspectives 43, 31-36.

Murugan A.M, A.J.A.Ranjit singh, and I. Joseph (2011) "Pyramidal effects on growth characteristics of the ground nut Arachis hypogea and black gram Phaseolus mungo. Journal of Ecotoxicology and Environmental Monitoring. 21 (2): 115 - 120.

Okoli, 0., Akas, P.A., and Nwafir, S.V., 2003. Anti inflammatory activity of plants. Journal Natural Remedies 3(1), 1-30.

Osario A.M and Goldman R., 2017. Proceedings from the Medical Workshop in Pesticide related illness International Conference in Pesticide exposed and Health. https.//books. google.co.in/ISBN1351226444.

Sree kumaran Nair and A.J.A. Ranjit Singh, (2002). Simple radioactive assay for the estimation of DNA breaks. 
J.appl.Toxicol. 22: 9-23.

Tiwari, U. Rastogi, B., Pararnjit Singh, Saraf, D.K., Suresh, P.V., Immunomodulatory effects of aqueous extract of Tridax procumbens in experimental animals. Journal of Ethnopharmacology 92(2004) 113 119.
Vinegar, R., Truax, J.F., Selph, J.L., Jilmston, P.R., Venable, A.L., McKenzie, K.K., 1987. Pathway to carragenan-induced inflammation in the hind limb of the rat. Federation proceedings 46, 118126.

\section{How to cite this article:}

Ranjitsingh, A.J.A., C. Padmalatha, G. Athinarayanan and Dhasarathan, P. 2018. Cell Mediated Immunity Dysfunction Retrieval Using the Extracts of the Plant Cassytha capillaries (Meissen). Int.J.Curr.Microbiol.App.Sci. 7(07): 3568-3574.

doi: https://doi.org/10.20546/ijcmas.2018.707.415 